\title{
The Shanghai Conservatory of Music and its
} Rhetoric

Building a World Class Musical Institution with Chinese Characteristics

\author{
Eugénie Grenier Borel
}

Translator. Peter Brown

\section{OpenEdition}

1 Journals

Electronic version

URL: http://journals.openedition.org/chinaperspectives/9391

DOI: 10.4000/chinaperspectives.9391

ISSN: 1996-4617

\section{Publisher}

Centre d'étude français sur la Chine contemporaine

\section{Printed version}

Date of publication: 1 September 2019

Number of pages: $27-35$

ISSN: 2070-3449

\section{Electronic reference}

Eugénie Grenier Borel, «The Shanghai Conservatory of Music and its Rhetoric », China Perspectives [Online], 2019-3 | 2019, Online since 01 September 2020, connection on 21 December 2020. URL : http://journals.openedition.org/chinaperspectives/9391 ; DOI : https://doi.org/10.4000/ chinaperspectives.9391 


\title{
The Shanghai Conservatory of
}

Music and its Rhetoric: Building a

World Class Musical Institution

with Chinese Characteristics*

\author{
EUGÉNIE GRENIER BOREL
}

\begin{abstract}
The Shanghai Conservatory of Music has as its principal mission the production of world class performers of "Western classical music" through a highly competitive training programme. This process of "globalisation" involves measures that are more explicit and more developed than in European or North American conservatories. The apparent absence of culturally-specific differences in this globalised model is more subtle than meets the eye, however. The globalisation is only partial, targeted, and above all accompanied by a form of appropriation involving two distinct mechanisms: the one devoted to the development and transmission of a standardised international performance technique, and the other concerned with the composition of pieces with particular Chinese characteristics, putting a nationalist discourse into music.
\end{abstract}

KEYWORDS: Shanghai Conservatory, Western classical music, globalisation, institutional rhetoric, nationalism, songs.

\section{Introduction}

7 his article deals with the way in which a particular institution, the Shanghai Conservatory of Music (known locally by its English acronym "SHCM"; in Chinese shangyin 上音), engages in a nationalist appropriation of what the West calls "classical music." The SHCM is an institution at once globalised and embedded within a specific cultural context. Its mission is to produce top-flight Chinese musicians who are competitive on the world stage, and who, like their peers abroad, are capable of "interpreting" this "classical" music in a perfectly international way utterly devoid of any national characteristics. In this article, I endeavour to show how the globalisation of a particular musical institution goes together with a kind of national appropriation, even though these may appear to take on two distinct rhetorical forms: the one devoted to the development and transmission of a globalised performance technique, and the other to the composition of pieces that bear Chinese characteristics overlaid by a nationalist discourse.

As is well known, music in China is a field in which the official discourse of the Chinese Communist Party (CCP) is used for propaganda purposes to exert power and influence, which inevitably raises socio-political questions. Historically in China, music has always been intimately bound up with the state from both a conceptual and social point of view. The country has long had state institutions called "Music Bureaux" (Trébinjac 2000), but it was only in the twentieth century that music became particularly instrumentalised through the rhetoric of both nationalism and communism.
A good example of this is the development of the textual content of "yellow music": what emerged in the 1920s as a style of music related to "jazz" (blending Western harmonic writing, Western instruments, and pentatonic melodies), treating romantic themes, reached a broad audience, first through the record companies EMI and RCA/Victor and later through the film industry, and quickly became the means of transmitting messages of political propaganda (Jones 1992).

The creation of the SHCM in 1927 is emblematic of the way in which this music took hold in China - a music regarded as "classical" in the West and whose assumed universality was adopted by the founders of the Conservatory - not only in the sphere of musical education, since it was the first institution of its kind in China, ${ }^{3}$ but also due to the fact that it was the site of debates about what should really constitute new Chinese music. ${ }^{4}$

\footnotetext{
I am grateful to Ellen Hertz for her careful reading and very helpful advice. I would also like to thank the anonymous assessors for their excellent suggestions. Any remaining errors or omissions are my responsibility alone.

1. In the course of this study, the expression "Western classical music" will be used to refer to what in the West is today called simply "classical music," a category of music that is to be understood as the European artistic tradition centred around composers from the seventeenth to the twentieth centuries, namely, a concept of music "firmly anchored in a particular set of compositions, and in a precise time and place" (Cook 1998: 15).

2. Following the importation of the harmonic system of Western music and American songs into China, an initial form of popular music appeared in the 1920s, composed entirely of the Western musical language and known pejoratively either as "yellow music"or"pornographic music" (huangse yinyue 黃色音樂) (Jones 1992: 11).

3. The Beijing Conservatory was not established until 1950.

4. For a detailed historical account of the various musical discourses in the context of the introduction of Western classical music, see the work of Joys Hoi Yan Cheung (2008).
} 
While the Conservatory provides a mixed curriculum today, combining Western classical music (xifang gudian yinyue 西方古典音樂), the dominant form, with Chinese music (Zhongguo gudian yinyue 中國古典音樂), it was only in 1956 that a department devoted to the latter was officially set up under the name of the Department of "National"5 Music (Minzu yinyue xi 民族音樂系) and under the direction of Shen Zhibai 沉志柏, one of the SHCM's own Professors (Kouwenhoven 1993: 74).

As an imported institutional model, the SHCM has as its principal mission the production, at the end of a highly competitive training programme, of international-calibre performers of "Western classical music," and accordingly it does its utmost to "globalise" its Chinese students so that they may be perfectly in step with the universally accepted standards of major international competitions. This strong engagement with the process of "globalisation" requires specific effort, both more explicit and much more developed than in conservatories in Europe or the United States. As such, it makes the Shanghai Conservatory of particular interest for a study of the importance of the "international" dimension and its close connection, in such an institutional context, to the acquisition and appropriation of the global project represented by this Western music that was created by Europeans as something universal. ${ }^{6}$

The first part of our study provides a brief overview of the components that make up this globalised model, in which we seek to bring out how internationalisation functions at the very heart of the institution. In pointing to certain socio-political and pedagogical elements we will see, however, that the SHCM presents particular local features that distinguish it from the Western model. Indeed, the students' performance of "Western classical music" evolves through the course of their studies, little by little shedding local features of learning in order to become perfectly international, and completely devoid, at least in appearance, of any connection to their place of origin and training. A second part of the study aims to understand how, conversely, a "national" dimension manifests itself. This is based on an analysis of two ensemble pieces by the Centre of Ideology and Politics, ${ }^{7}$ one of the 15 departments that comprise the institution. This Centre adopts several different rhetorical stances with a nationalist feature, three of which will be explored here. The first two are expressed through songs: through musical elements such as pentatonism, i.e., music using a fivetone scale, affirming Chinese characteristics within the context of a tonal writing system, then through a textual and visual production of these same songs that gives prominence to a certain type of emotional expression. The resulting musical creations associate or juxtapose different stylistic categories within their compositional writing, thereby having the effect of blurring musical genres that are usually separate in Western musical institutions. The third example that I will analyse briefly concerns music that a new research programme, formed on 18 October 2018 out of the above-mentioned Centre of Ideology and Politics, is charged with making an inventory of and is studying as part of its mission to promote research into Chinese "red music" and its development.

My study is based on observations and interviews we made during two ethnomusicological fieldwork trips, the first conducted between September and November 2017 and the second between March and May 2018, as well as information we have been able to gather from social media. This ethnography of the particular has the aim of analysing practices and discourses that are present in the context of the training in the performance of Western classical music; it sets out to show how the "Chinese" dimension, and what that implies in terms of national uniqueness, is translated into the discourse and practice of an institution that was founded according to a Western model. I will also present an analysis of the two musical pieces mentioned above. On the basis of this corpus I will analyse the dual rhetoric of the institution - on the one hand, a desire for internationalisation, and on the other a desire for Chinese-style nationalism - illustrating how these aspects of "musical worlds in transformation" (Becker 1982) contribute to the creation of new musical "spaces."

\section{Context and approach}

As an institution, a conservatory is a world with which I am familiar. For the past 15 years I have taught piano in a conservatory after having being a student myself in various such institutions, both in Switzerland and abroad (United States of America). In my role as a researcher in China, I was thus an insider as well as an outsider: as a member of the world of music, I was an insider, while as a Westerner, and someone who is not part of the Shanghai Conservatory of Music, I was clearly an outsider. My position as an insider meant that I was familiar with the semantic conventions of music and its performance, as well their representations. On the other hand, being an outsider exposed me - in particular at the beginning of my stay - to the reticence of those I interviewed, both male and female, who, unsure of my background and motives, were reluctant to come forward with comments that might be seen as critical of their institution. This dual dimension, together with its accompanying constantly blurred line of demarcation, was not easy to manage. But my insideroutsider status has also been an advantage, in that it led to a questioning of the idea of belonging to either one or the other of these categories. During the interviews, people often made comments on my status as an outsider; then, as the conversation proceeded, the tenor of the content led to an insider-to-insider relation of confidence. The movement back and forth between these two positions often contributed to enriching the content of the exchanges. Overall, there are similarities between my experience and that of Howard Becker, who, in his ethnographical account of the world of jazz musicians, noted his observations through his own integration as a pianist (Becker 1963; for a related experience in the AfroAmerican world of boxing, see Wacquant 2000).

5. The translation of the term minzu, employed by the Department of Chinese Music, calls for some comment. It can refer to three notions: the nation, nationalities, and ethnicity. In 1962, the Chinese State and the CCP decided to unify the translation of the three different terms into the single "minzu," in order to adhere to the political principle of unity among the nationalities, whether the "Han" or ethnic minorities (Thoraval 1999). The term minzu thereby produced a tension between the different translations, which lie at the heart of the way in which Chinese anthropologists either accept as a given or question the official categorisations of the national population (Thoraval 1999; Barabantseva 2008)

6. To gain a deeper historical understanding of the development of the idea of universality associated with Western classical music, see Matthew Gelbart (2011). His analysis shows how, in the late eighteenth century, a dichotomy arose between folk music (which would become "traditional" music) and "art music" at the time of the construction of the concept of the nation, and how nationalism cystallised debate over the origins of music rather than its functions. This aesthetic hierarchy between "folk" music and "art" music placed the masterworks of the latter at the pinnacle, assumed to be universal and timeless precisely because the composer's genius lay in absorbing and synthesising the "people" as a collective whole by sublimating works of folk music (at the regional, national, and supranational levels) within an individual piece of music.

7. The full name is Shanghai Conservatory Centre for Teaching and Research in Theoretical Instruction in Ideology and Politics (Shanghai yinyue xueyuan sixiang zhengzhi lilun ke jiaoxue yanjiu zhongxin 上海音樂學院思想政治理論課教學研究中心), abbreviated to Centre of Ideology and Politics (Sizheng zhongxin 思政中心). Its objectives, as described on the Conservatory's website, are to enhance the ideological and political quality of the students, deepen their level of theoretical thinking, help them to master modern professional knowledge and skills, and develop the "all-round acomplishments" of the best musical talents. 


\section{The place and its history}

The Conservatory district, situated in one of the leafy streets in the heart of the former French concession of Shanghai, juxtaposes very different worlds and lifestyles. The campus buildings reflect the eclectic architecture of the area, in that they combine structures dating from the concession era, former residences of public figures, and more recent notable constructions such as the concert hall of the Shanghai Symphony Orchestra, completed in 2014 through the collaboration between architect Arata Isozaki and acoustician Yasuhisa Toyota. The site of the SHCM continues to be developed, and is currently preparing to house, in the context of the $90^{\text {th }}$ anniversary of its establishment, an enormous opera house that is the work of the architect Christian de Portzamparc, among whose previous achievements is the Cité de la Musique in Paris.

The establishment of the Conservatory in 1927 marked the beginning of a new period for music in China with the institutionalisation of the teaching of Western classical music. ${ }^{8}$ Its creation, a first in China, was emblematic of musical education at the time. At the outset of the twentieth century, in the semi-colonial and cosmopolitan context of Shanghai, ${ }^{9}$ this music, imported as the result of a political decision, was what had to be mastered, and therefore studied, as it was identified with modernity. The initial contacts with Western music had already taken place through education by missionaries, who used singing for religious and educational purposes and also introduced the teaching of the piano and violin. In 1898, a major change occurred within the reformist movement of the Hundred Days, led by Kang Youwei 康有為 and Liang Qichao 梁啟超, which would see Western music become dominant in China (Gong 2016). This took place in two stages, beginning with the adoption of the Western-style military brass band. This was a decision taken by Liang Qichao, who believed that Western music was more powerful than Chinese music for motivating, disciplining, and coordinating the troops of the Chinese army (Melvin and Cai 2004). The second stage came with the teaching of singing, in the context of reforms to education, under the influence of the so-called "school song movement" (xuetang ge 學堂歌), inspired by the examples of Germany and Japan. These songs, adapted from the Western model that had been introduced a halfcentury earlier in Japan, inculcated in millions of children the basic elements of the Western musical language. They were partially constitutive of what would be called "the new music." 10 Only the written texts were subject to being changed, taking on Chinese characteristics that fitted the framework of nationalist thinking, and in particular serving as a vehicle for advocating scientific knowledge (Trébinjac 2000).

For the Conservatory's founder, the musician and reformist Xiao Youmei 蕭友梅, the establishment of a formal system of musical education based on European methods was a priority for China. This system was not devoted solely to Western classical music; it also had to embrace Chinese music by transforming it into a standardised and improved version. For the reformist Xiao Youmei, the spread of this system, with its own teaching methodology, needed, in the long term, to enable the New Chinese Music to be considered fundamentally international, in the process rendering obsolete its characterisation as "Western" (Cai 2004: 95). ${ }^{11}$

\section{Observations}

\section{Similarities}

The courses I attended during my two stays at the Shanghai Conservatory had many points in common with those of other conservatories, in Europe and the United States, in terms of both form and content. I observed without great surprise that the difficulties encountered by students, associated with the writing of this music and its musical forms, often corresponded to what one finds in comparable Western institutions. Even less surprising were the difficulties attributed to what is commonly called "technique," an umbrella category for everything to do with the body's adaptation to the instrument, as this is a generalised phenomenon - our body being "essentially endowed with the same capacities and the same limits" (Clarke 2014: 351). The repertory that was taught, such as it appears in the standardised Bachelor's and Master's programmes, is broadly the same, with the exception that, in Shanghai, the annual curriculum also includes a piece by a Chinese composer. The weekly classes involve one-to-one teaching, and relations between teacher and student are also similar. In the West, the figure of the maestro derives its legitimacy and authority from what is deemed to be a line of continuity going back ideally to the composers themselves, and students at the SHCM also have a relationship of devotion to their teachers that is characteristic of the teaching of music in Western institutions. ${ }^{12}$

In terms of organisational structure, this particular relation to the figure of the maestro is accompanied by a kind of group dynamic that works as a system of patronage (Kingsbury 2000), whereby a group of students gravitates entirely around a particular teacher. I observed at the Shanghai Conservatory that this modus operandi tended to be strengthened by two factors: on the one hand, a range of activities emphasising the compartmentalisation of instrumental teaching, and on the other, by the strong competition between students, which does not encourage them to go beyond their group much less their musical department. The ethnomusicologist Frank Kouwenhoven remarked, in a lecture he gave in Shanghai in October 2017, on how just such a compartmentalisation structures the SHCM, organised as it is into departments that function "like

8. Initially, it was under the name of the Higher National School of Music (Guoli yinyueyuan 國立音 樂院), and under the aegis of Xiao Youmei and Cai Yuanpei, that the musical institution came into being. The term yinyueyuan 音樂院 (instead of 音樂學院), is, according to Enamoto Yamoto, the real equivalent of the word "conservatory," a deliberate choice by Xiao Youmei, who wanted the school to be, from its very inception, a conservatory made in the image of the Western model and not an academic Faculty (Yasuko 1998: 149). In 1929, it was renamed "National Specialist School of Music" (Guoli yinyue zhuanke xuexiao 國立音樂專科學校), which meant a three-year training programme, a "deliberate reduction" by the government of the status of the musical institution to the level of professionalsSchool, accompanied by a drop in the level of financial support (Kouwenhoven 1993: 62; Yasuko 1998: 137). In 1938, at the time of the Japanese occupation, it even became the "Shanghai Private School of Music"(Sili Shanghai yinyue yuan 私立上海音樂院) in order to avoid any association with the Chinese government (Kouwenhoven 1993: 68). Between 1949 and 1956, there were four further name changes before the adoption of the current one, "Shanghai National Conservatory" (Shanghai yinyue xueyuan 上海音樂學院). Each of these stages reveals the tension between an "international" perspective and the national political interests that have characterised this institution ever since its foundation.

9. For a detailed study of the way in which Western music has been accepted and developed in China, covering the period from the early 1920s until the 1930s, we refer to the thesis by Enamoto Yasuko.

10. In the introduction to his work New Music In China, the musicologist Liu Ching-Chih (Liu Jingzhi 劉靖之) gives a detailed account of this New Music, which must be understood as an emic term, that is, seen from an internal perspective, in the context of twentieth century China, and not one deriving from a European perspective. In her 1997 book Dangerous Tunes, Barbara Mittler defines the New Music as follows: It is the co-existence of the Old and the New, the manifold response to the Western and the Chinese musical heritage, an almost post-modernist embracement of diverse types of musical trends and styles, the citation of the most diverse conventions, sometimes in one and the same composition which makes New Chinese Music become New Music in the Western sense of the word" (Mittler 1997: 20-1).

11. Xiao Youmei was, according to one of the professors of musicology at the Conservatory, a leftwing musician, a moderate "academician." The reformists of the day were divided into two groups: "academicians" (xueyuan pai 學院派), and "salvationists" (jiuwang pai 救亡派). While they had divergent views as to how the new music in China was to be conceived, they shared the same concern for the long-term realisation of the "Chinese nation" (Zhonghua minzu 中華民族), i.e., an "imagined community" to be invented under the influence of Western thinking by means of music.

12. The musical biographies introduced by reformers such as Xiao Youmei and Wang Guangqi 王光祈 presented European classical composers not only as musicians from a foreign culture, but "as 'maestros' who were both virtuous and worthy of admiration" (Cheung 2008: 290). 
islands," allowing for virtually no exchanges between them. Within each department, I noticed that the various groups did not mingle with each other, and even tended to view each other as rivals in a context of intense competition. Students in a particular class are engaged in many different activities within their group. An example of how this works may be seen in the following: an ensemble of young pianists of the pre-professional section of the Conservatory, ${ }^{13}$ following the Chinese term fuzhong 附中, took part in a broadcast on Beethoven led by their teacher, who put them on display as the sole audience ${ }^{14}$ before they, in turn, performed as an ensemble with as many grand pianos as there were pianists, and with their teacher as the focus of the whole show.

The Shanghai Conservatory is therefore in no way an exception to the institutional arrangements that characterise a Western conservatory, either in its pedagogical practice or in its organisational chart. Moreover, it is not exceptional in terms of teaching content. Following a global model, teaching in the Conservatory reproduces a framework of apprenticeship in which the challenge consists of performing the masterworks of the great composers, a repertoire whose musical scope shrank in the nineteenth century (Vendrix 2004: 639), and mainly includes pieces that are referred to by the surname of the composer or simply by the "opus number" - this is the prestigious repertoire. This was at any rate my clear impression in observing various instrumental classes day after day, seated in one corner of the classroom. What I saw was familiar to me - the cup of green tea offered to me as a sign of welcome by the various professors being the sole reminder that I was in Shanghai and not in New York, Berlin, or Geneva.

These succinct observations lead me, however, to stress the fact that such an ethnographic study of Western classical music helps us to see that we are not "embedded" in a single culture but rather are impregnated with a number of different references. The study of a particular music, both in terms of its practice and its discourse(s), enables us to demonstrate how a community that shares the same music, "now transnational and thoroughly globalised in all of its dimensions: performative, composerly and in its reception" (El-Chadban 2009: 156, quoted by Nooshin 2011), nonetheless constructs its own references, fashioned by a complex web of social, political, economic, and artistic factors.

\section{Relativizing similarities}

This apparent disappearance of differences with respect to high-quality music is more subtle than meets the eye, however, and calls for a nuanced commentary. The globalisation involved in the training is actually only partial, and targeted for specific purposes: it concerns, for example, only one part of the classical repertoire in the teaching programme of the preprofessional section, the part that matters for winning a prize in international competitions. In contrast to this, contemporary and/or baroque compositions are excluded, while the existence of European musical forms dating from the Middle Ages or the Renaissance is purely and simply ignored. More generally, some aspects of the education system and the social system more broadly have an impact on the choices made, such as that of the repertoire or certain approaches to learning/teaching methods. Close observation enabled us to gauge the role of a certain number of elements, which can be circumstantial as well as musical and socio-political, that characterise the training of musicians in this Conservatory. While students seem to be in an institution that is connected to the classical music community worldwide, encouraging a great variety of exchanges, they are also living within a state with an ideology of meritocracy, in a context both of extreme competition and of an authoritarian regime: "The state controls society, and the party controls the state. There is a double system of control" (Ringen 2016: 1).

The new rules applying to the general education system are changing the mode of recruitment of young musicians, with a direct impact on exam preparation and the repertoire. These rules come directly from the central authorities, bypassing all the intermediate levels (Kipnis 2011:9), a trend that has become much more marked after the post-2012 changes to governance "in the concentration of power at the centre" (Ringen 2016: 11). The official place and appreciation of music currently shown by the Chinese Communist Party through these new rules is producing new ideological directives within the national conservatories, a sign of the way in which the CCP views the official place of music and its intention to promote this. One recent example is provided by a directive announced on 21 March 2018 by the Xinhua News Agency, ${ }_{1}^{15}$ which stipulates that henceforth only high school students who choose music or the arts in addition to the compulsory subjects may receive bonus marks over and above their raw score in the gaokao 高考, ${ }^{16}$ the unified national competitive exam for access to general higher studies and a pre-requisite for matriculation into the country's universities. This limitation (it is no longer possible to obtain marks through choices other than musical and artistic subjects) puts young musicians and artists in a separate category, enabling them to keep the marks they receive in the music exams to use them when they sit for the gaokao. Further, they only need to score 300 (out of a total 750) to pass the latter - and this minimum entry score may itself be revised downwards if the applicant is supported by a teacher wishing to enrol him or her in their class. ${ }^{17}$ These privileges, testifying to the growing prestige of musical training, constitute a strong encouragement to parents to have their children follow such an educational path.

The Chinese system means that a decision taken at the top can have a profound impact on the standing of musical studies, in a context that is promoting careers in music. If we also take into account the fact that the principal mission of the Conservatory, through its pre-professional section, is to train soloists, we can understand that this trend is linked to the increased importance of international recognition. The teaching programme of the pre-professional section of the SHCM is the perfect illustration of an education that is entirely devoted to the training of soloists. A considerable amount of media attention is also given to promoting this, as shown by the anthropologist Andrew Kipnis in his work on Zouping County (Kipnis 2011: 37), in which he depicts an attitude of glorification with respect to talented students - posters featuring the

13. Since 1952, the Shanghai Conservatory has had an intensive pre-professional section offering both pre-professional musical training and a general academic curriculum, designated by the term fuzhong 附中. This currently provides for around 600 students between the ages of 10 and 18. Although it is attached to the Conservatory, it remains independent of it in terms of both its organisation and its pedagogical choices.

14. This was a programme made for the Shanghai Media Group on the occasion of the $190^{\text {th }}$ anniversary of Beethoven's birth.

15. The system of bonus points, according to these new rules, is not applicable to high school students who, in addition to the compulsory subjects, take Olympic sports or take part in STEM competitions, or to those who have received the accolade of outstanding student at the provincial level, or who have performed actions deemed to be heroic in the field of ideology and morality, options that previously (until March 2018) could attract bonus marks. See "教育部: 2018 高招 全面取消體育特長生, 奧賽等高考加分項目" (Jiaoyu bu: 2018 Gaozhao quanmian quxiao tiyu techang sheng, aosai deng gaokao jiafen xiangmu, Ministry of Education: 2018 decision to do away with the programme of bonus marks in the gaokao for students with outstanding ability in sport, taking part in elite competitions, etc.), Xinhua, 23 March 2018, http://www.xinhuanet.com/ yuqing/2018-03/23/c_129835876.htm (accessed 24 July 2019).

16. In addition to the gaokao 高考, music students must sit the yikao 藝考 in February, an exam testing professional skills, consisting of two parts: the liankao 聯考, which concerns only provincial regions, and the dankao 單考, an exam conducted by each conservatory.

17. According to the testimony of one female teacher at the Conservatory, the Education Bureau has regularly introduced changes, a source of anxiety for parents ("Every second or third year revolutions take place within the Education Bureau"). 
best students are given high visibility. ${ }^{18}$ The taught repertoire maps what is commonly found in the programmes of international competitions, consisting of a selection of composers and set pieces. We note, however, that in the fieldwork interviews we conducted this choice attracted criticism from some teachers in both the pre-professional and professional sections of the Conservatory.

The SHCM offers a concrete illustration of these policy and political changes with respect to the teaching programme. The head of the Conservatory, who since its foundation has always been either a musician or composer, is currently the scholar Lin Zaiyong 林在勇, appoint ed in 2015 as successor to the composer Xu Shuya 許舒亞. In addition to taking on several official functions - Party Committee secretary, President, and Professor of the SHCM ${ }^{19}$ - Lin Zaiyong also contributes to writing the lyrics of songs produced by the Conservatory (one of which will be illustrated below). In a speech he gave on 19 June 2018, on the occasion of the introduction of a new course devoted to the study of the ideas of Xi jinping ${ }^{20}$ entitled "Teaching the builders and successors of socialism: Developing a world-class Conservatory that is also very Chinese," the institution is presented as having the mission of contributing to realising the Chinese dream (Zhongguo meng 中國夢) of rejuvenating the Chinese nation. ${ }^{21}$ This new course is thus an active component of the enhancement of a nationalist programme within the institution, turning the teaching of Western music into something that is very closely controlled by the authorities and imbued with a strong political message.

\section{Memorisation and scientific approach to reading a musical score}

Memorisation of the repertoire, required by teachers for every course, demands that students commit themselves to a repetitive daily routine for "as many hours as they can,"22 pushing them to the limit of what is humanly possible within the context of a curriculum that already provides for activities throughout the day. It involves developing an ability to memorise an important number of standard repertory pieces for public performance. ${ }^{23}$ One young female pianist explained to me that what was uppermost during her pre-professional training at the SHCM was the execution, from memory, of each and every notation on the score, right down to the fine detail. Students must consequently carry out these instructions to the letter, as if there were something sacred about them. I was able to observe that the teachers promote a "scientific" approach to this notation, and indeed to this whole musical tradition, when, for example, they refer to "the scientific system of tonal harmony" or "the technical precision" of such and such a sign. During my interviews, expressions such as "learning such and such a technique," or "mastering a scientific system" were frequently used. ${ }^{24}$

These practices, associated with the scientific characterisations of a technological discourse, invite us to think of the score as a stable entity, external to the musician. The consequence of this is that it is kept at a distance. In the case of the female student who described her preprofessional training at the SHCM, she said that she had to be "faultless" with respect to the execution of this notation before being allowed to develop "a personality" - which was only supposed to come much later. This objectification of the score, associated with training through repeated memorisation, therefore sets up a process of distanciation that changes one's perception of the musical text and the relation of body to instrument, two factors that can inhibit the expressive dimension of the performance and consolidate the teaching of Western classical music as essentially a matter of know-how, the principal focus of which is the production of internationally recognised soloists.
More generally, this scientific outlook is related to an implicit but widespread discourse, "forged when musicians, theorists and politicians positioned themselves with respect to Western music" (Cheung 2008) at the dawn of the twentieth century. For the musicologist Joy Hoi Cheung, one part of the current institutional and pedagogical practices of the Conservatory stems directly from this historical formulation. Moreover, as Andrew Kipnis suggests, this scientific language "is increasingly central to education in China and serves as a justification of the politics of the regime." 25

\section{Efforts in globalisation}

As indicated above, a defining feature of the Shanghai Conservatory of Music lies in the importance given to the international dimension. Admittedly, the mission to produce international-calibre performers of Western classical music through a competitive training programme is not exceptional in itself. Similar institutions in Europe, the United States, and other parts of the Western world all have this is common. This aspect is nevertheless particularly present and explicit in Shanghai, where a saying of jiang Zemin 江澤民 is engraved on the walls of the Conservatory: "Offering first-class music education and becoming internationally advanced"26 (ban yiliu yinyue jiaoyu, chuang guoji xianjin shuiping sili Shanghai yinyue yuan 辦一流音樂教育, 創國際先進水平私立上海音樂院). This motto also appears in the brochure published in 2018 on the occasion of the $90^{\text {th }}$ anniversary of the Conservatory.

18. The supreme accolade would be to attain "famous musician" status, a "yinyuejia" 音樂家, that is, an emblematic figure in the field, like the pianist Lang Lang, who is presented as a hero in the national rhetoric

19. According to the SHCM's official WeChat account, dated 22 June 2018, this ideological and political course, on the general subject of "Cultural China" (Wenhua Zhongguo 文化中國), is taught by the Conservatory's President and Party Committee secretary, Lin Zaiyong. It is also broadcasted on radio under the title "Let's fight together, my country and me!" (Fendou ba, wo he wo de guo! 奮鬥吧, 我和我的國!). This course draws its inspiration from a speech promoted by the Service of the Party Committee of the Shanghai Centre, the Centre for the development of the moral education of Shanghai students, the Shanghai channel of the People's Network, the Shanghai Media Group, and the educational television channel of Shanghai.

20. This is a course offered by all Shanghai universities, following an official announcement of the Ministry of Education to promote the spirit of a speech Xi Jinping made during his meetings with teachers and students at Peking University during the 200th anniversary commemoration of the birth of Karl Marx. In this connection, the SHCM organised a similar course devoted to an indepth study, with practical exercises, of the spirit of this speech: “習近平: 在紀念馬克思誕辰 200 周年大會上的講話” (Xi Jinping: Zai jinian Makesi danchen 200 zhounian dahui shang de jianghua, Xi Jinping: Speech delivered on the occasion of the $200^{\text {th }}$ anniversary of the birth of Karl Marx), Xinhua, 5 April 2018, http://www.xinhuanet.com/politics/2018-05/04/c_1122783997.htm (accessed 24 July 2019).

21. "Realising the rejuvenation of the Chinese nation" (Shixian Zhonghua minzu weida fuxing de Zhongguo meng 實現中華民族偉大復興的中國夢) is a strategic orientation announced by Xi, most notably at the $19^{\text {th }}$ Party Congress, whose roots go back to the CCP's seizing power in 1949 via the voice of Mao: “習近平説, 實現中華民族偉大復興的中國夢是新時代中國共產黨的 歷史使命” (Xi Jinping shuo, shixian Zhonghua minzu weida fuxing de Zhongguo meng shi xin shidai Zhonguo gongchandang de lishi shiming, Speech by Xi Jinping: Realising the rejuvenation of the Chinese nation is the historic mission of the Chinese Communist Party of the new era), Report of the $19^{\text {th }}$ Congress of the Chinese Communist Party, 18 October 2017, http://cpc.people.com. cn/19th/n1/2017/1018/c414305-29594243.html (accessed 24 July 2019).

22. Interview with three piano students, Shanghai, April 2018.

23. The form of a concert featuring a soloist, in which everything is played from memory, is a tradition dating back to the mid-nineteenth century, originating with Franz Liszt, who is credited with inventing the genre.

24. It has become quite standard for a curriculum vitae to refer to "mastery of accordeon technique" or "mastery of piano technique." During the oral defence of a thesis in musicology, one female student explained to me that it was necessary to show the "scientific approach" of such and such a Western composer - from memory, without recourse to notes.

25. Kipnis explains that "Policies are defended as scientific, and the teaching of both politics and sciences in schools treats the concept of 'science' as a sacred term" (Kipnis 2011: 8).

26. According to the 2015 edition of the Shanghai Conservatory of Music Booklet, https://www. slideshare.net/LimTeikChuan/shanghai-conservatory-of-music-booklet (accessed on 19 July 2019). 
In practice, the importance attributed to the international dimension is manifested in the form of trips abroad by Chinese students being financed by the Conservatory. It has put in place a number of MoUs with other musical institutions, primarily in Cermany ${ }^{27}$ and the United States. I noticed that part of these overseas trips involves participating in international competitions over a limited period of one or two weeks. The emphasis on the international aspect is also apparent in foreign musicians and experts being invited to Shanghai throughout the year to give a series of master classes and lectures. This testifies to an operation in which the validation of teaching and the authenticity of style are based on Western expertise provided by Western experts.

This international dimension is an important part of the Shanghai Conservatory's identity, as perceived in particular by its members. For those whom I interviewed, both male and female, the Conservatory is a symbolic site, the starting point of the teaching of Western classical music, with respect to Beijing: "We are the 'motherland'." There is a twofold claim of legitimacy, both within China and abroad, reinforcing the particular nature of Shanghai as a cosmopolitan city focused on the West. As Ellen Hertz notes, associating Shanghai with words such as "Western" and "international" encourages "an implicit contrast with Beijing" (Hertz 2009: 211), stressing its image, so dear to its residents, as China's premier Westernised city.

\section{The processes of reappropriation: An example of two pieces of ensemble music}

Based on an analysis of two pieces of ensemble music composed in 2013 and 2018 , I would like to show how, musically speaking, internationalisation is made to serve nationalism, putting forward a new meaning to the expression "Chinese characteristics." By associating or juxtaposing different categories such as "Western classical music" (Xifang gudian yinyue 西方古 典音樂) and "pop music," i.e., commercial music (shangye yinyue 商業音 樂), these compositions also blur and reshape their boundaries in a different way from what usually occurs in Western musical institutions, where the tendency is to separate them. While these examples clearly illustrate this in a musical sense, this shift in taxonomy first emerged in the discourses themselves. In my ethno-musicographical research, I paid particular attention to use of certain terminology, such as"world music"(shijie yinyue 世界音樂), "new music" (xin yinyue 新音樂), or "national music" (minzu yinyue 民族 音樂).

It was sometimes thanks to misunderstandings that transpired during these exchanges with my informants that I was actually able to understand that there are different ways of categorising this music. These misunderstandings, which became heuristic tools, helped me become aware of the malleable dimension of the boundaries that, in the context of my presence in Shanghai, were the subject of implicit negotiations.

One example may serve to illustrate this. The occasion was a dinner party to which I had been invited and where the person sitting on my left was a composer. When I mentioned to him the name of one of his colleagues, I could see there was some confusion. The misunderstanding was eventually resolved: my neighbour had found it difficult to pinpoint the composer I had mentioned (whom he knew well) because I had referred to him as being part of the Shanghai group of composers. In the mind of my fellow dinner guest, the composer I had alluded to belonged in the category of "contemporary music" and not in that of composition, whose scope covers mainly Chinese national composition. The category of "contemporary music" was thus separated from the world of composition as a whole, something I was expecting all the less in that, from the point of view of a
European conservatory, a contemporary (living) "composer" can only be associated with the world of contemporary music. It goes without saying that this differentiation is likely to resurface when the notion of "composer" is extended beyond the scope of its meaning within institutions teaching classical music.

\section{"The Return of the Century"}

The song "The Return of the Century" (Shiji guihang 世紀歸航) was written in 2013 by three teachers at the Conservatory before being staged to celebrate the centenary of the Association of Chinese Students in Europe and the United States. A symphony based on this song was composed and filmed with English subtitles. ${ }^{28}$

The song was broadcasted by the Shanghai Conservatory's Centre of Ideology and Politics. This Centre has gained increased prominence by dint of the fact that the Conservatory's President took part, as a Professor, in the ideology and politics course. Besides spreading information, this Centre offers courses at the undergraduate, Master's, and PhD levels on public culture, the theory of political ideology, and physical education. ${ }^{29}$ This academic unit is directly answerable to the Party Committee of the Conservatory. The song, based on a text by Yang Sai 楊賽, who is in charge of research in the Centre of Ideology, and put to music by Li Jia 李嘉, won third prize in the competition for the best text inspired by Xi Jinping' $\mathrm{s}^{30}$ speech entitled "Study the speech, raise the flag" (xue jianghua, ju qizhi 學講話, 舉旗幟).

The video of "The Return of the Century" shows the soloist and vocalist $\mathrm{Li}$ Tao 李濤, accompanied by students of the Conservatory who formed a kind of Western symphonic orchestra conducted by the seasoned Cao Peng 曹 鵬. According to the criteria of Western musicology, the genre of "popular songs" is not only characterised by an orchestral writing and a repetitive structure of verse-chorus as its founding principle, but is also identified by its relative brevity and the recurrence of textual and/or musical elements that have a regular metric dimension to them (Fabbri 2001: 677). This also holds true for the textual segmentation, organised in stanzas of four lines of verse, thereby creating quatrains. This segmentation models itself on a musical writing that is repeated independently of the text.

The orchestration, arranged for both the melody and the images, entrusts the instrumental ensemble with a role similar to those of symphonic pieces that accompany television productions. This first distinction is made apparent by the fact that the orchestral writing calls on hardly any polyphonic voices and does not bring any elements different from those provided by the vocals. The orchestra, serving the voice, can amplify it by reproducing it in a kind of echo effect, for example when the xylophone repeats the song an octave higher. Sometimes it intervenes by interspersing ornamental micro-figures played by the strings or percussion instruments (bells, triangle), a mimetic effect by which it completes the video clip of the musical performance, thereby reinforcing the dramatic aspect of the recital.

This process of orchestral writing is not, therefore, like symphonic writing

27. The Conservatory is one of the main partners of Hamburg's Hochschule für Musik und Theater, which has a common programme for students on exchange within the framework of the partnership between the cities of Hamburg and Shanghai.

28. The song can be found on Chinese websites such as people.com.cn and China.com, and can be viewed at the following link: https://v.qq.com/x/page/i0503l3uq8f.html (accessed on 5 September 2019)

29. "Public Culture" (Gonggong wenhua 公共文化), "Theory of Political Ideology" (Sizheng lilun 思政 理論), and "Physical Education" (tiyu 體育).

30. Speech given on 21 October 2013 on the occasion of the centenary of the Association of Chinese Students in Europe and the United States. A summary of the speech can be found at http://www. shcmusic.edu.cn/view_22.aspx?cid=104\&ppid=36\&id=6\&navindex $=0$ (accessed on 26 July 2019) 
for programme music or producing "pure" music, i.e., where the material is sufficient unto itself. Instead, it corresponds more to a way of producing sonic textures for something else, in this case the voice and the images. This shows a distance with respect to the importance given in the history of composition in Western classical music to the development of polyphony, which was established as an essential principle of composition in the West (Meeùs 2004: 116). Calling on a particular choice of repertoire, it enacts a shift in musical taxonomies, in the process introducing a porous border between the categories of "Western classical music" and "popular music."31 By its galvanising nature, as illustrated by the rising sixths that conclude on a descending harmonic sequence, the general tone can only lead to a grandiose ending. This is presented by the soloist's long, high-pitched flourish that reinforces the sense of glory in reference to the text being sung.

This writing, whose sections belong to the seven-tone scale system of Western music, is punctuated by melodic patterns built on a pentatonic scale. This "pentatonisation" falls under the guidelines of successive Chinese governments in terms of characterising "correct" Chinese music, namely a national style that is clear and pure (Mittler 1997: 281). This idea can be found in the words of the composer He Lüting 賀綠汀, the founder of the pre-professional section of the Shanghai Conservatory of Music, whom the ethnomusicologist Barbara Mittler quotes in her work Dangerous Tunes: "The pre-eminence of melody, conceived as a monodic line that can be doubled by a consonant voice with pentatonic outlines, is an essential aspect of China's musical heritage."132

\section{"Conservatory, my Love"}

The second example is a song called "Conservatory, my Love" (shangyin, wode ai 上音, 我的愛), a piece of music that was staged and filmed and dedicated to the Conservatory for its $91^{\text {st }}$ anniversary celebrations. ${ }^{33}$ The lyrics are by Lin Zaiyong 林在勇, the President of the music institution, and the music was composed by Zhang Qianyi 張千一.

\section{"上音, 我的愛" - "Conservatory, my love"}

是誰讓我如此深愛 I love you deeply
是誰讓我如此難忘 This school is unforgettable
她是生命的理想 It is an ideal of life
她是音樂的殿堂 It is the spiritual place of music
你的琴悠揚在我胸膛 Your melody floats in my heart
我的心在為你歌唱 My heart sings for you
因為有了你世界從此變得不一樣 Your existence has changed the world
靜䍀之地有大師的足迹和氣場 In this calm place lie the footprints and
charisma of great masters
動感時刻有青春的身影和光芒 During lively times, there are the shape
and light of youth
最好的我献給你 I give you the best of myself
最美的你駐我心房 You, the most beautiful one, live in my heart
就算我在你身旁 When I am right next to you
我依然忍不住思念神往 I cannot stop thinking about you
離開你的日子 When I leave you
天涯海角你依然是我的夢鄉 In faraway places, you are still in my dreams

This song, both in its musical texture and in its performance, is reminiscent of Western, and particularly Italian, opera. The melodic contours and the harmonic writing are in "the Italian style" in their reference to bel canto lyricism as opposed to German opera, associated with Wagner's writing for voice - which is primarily in the service of the drama. The style of performance presented underscores the characteristics of Italian opera through theatricalised expansive body movements that are features of lyrical singing, in strong contrast to the voices of two children heard at the start of the song. This opening, performed by two young students dressed in the uniform of the music institution and placed in front of the Conservatory's oldest building, has all the hallmarks of a children's song, which itself recalls the way in which Western music came to have a dominant position in China, namely through the "school song movement" (cf. supra).

In the second part, lyricism gives way to a more rhythmic and vigorous section, in the manner of Verdi in his triumphal march for Aida. The major chords, the pointed rhythm, and the dynamic images showing the young musicians moving through the corridors of the music institution situate this central part, through its ebullient, robust character, at the heart of this song, promoting especially a dynamic image enhanced by the production of the video.

The way the song is built up on a single crescendo concludes, as we saw in the example of the first song, with a grand finale, sung in the upper register. This kind of progression is to be found in the overture to Wagner's opera Tannhäuser, mutatis mutandis, which is also constructed as a single arch with a majestic finale. The main motif of the melody, as with the song "The Return of the Century," is structured on the pentatonic scale within writing that is fundamentally tonal.

While, musically speaking, the song is evocative of Italian opera (with a more "Germanic" touch in the finale), the song text itself has nothing in common with the standard themes found in the libretto of such lyrical works. Its content is related to the more general, and very political, idea that it must illustrate feelings that go well beyond the "love/friendship relations" between two individuals. Thus, beyond giving vent to any emotion towards the music institution and its founder, Xiao Youmei, it is about expressing one of the central themes, the love of the homeland and its leaders. This rhetoric is historically conveyed by the voice of the influential "activist musician" Lü Ji, as explicitly illustrated by the words of the song "The Return of the Century" (Trébinjac 2000: 52-7). Further, phrases such as "It is an ideal of life" or "It is a spiritual space of music," with overtones of Confucianism, relay the motto of the Conservatory, as expressed in the four characters: "harmonious, perseverant, serious, honest" ${ }^{\prime 4}$ (he yi zhuang cheng 和毅莊 誠). A number of themes embed this general rhetoric within values that are traditionally attributed to Confucius $s^{35}$ : for example, the value of transmission of culture from one generation to the next, as embodied by the conductor's

31. It is interesting to note a musical custom in Chinese musical history, following the example of the situation in Europe and before the break at the end of the thirteenth century, as outlined by the musicologist Matthieu Gelbart (2011). Liu Ching-chih describes the combination of popular music and court music that has been around since the Xia, Shang, and Zhou dynasties, in which folk music, popular music, religious music, court music, traditional opera, and literary music are all combined (Liu 2010: 11).

32. Barbara Mittler points out in her work that it is important to define what "correct" (zheng 正) Chinese music is. The ethnomusicologist also uses the expression "pentatonic romanticism" to describe a type of music that draws on the harmonic context in Europe in the late nineteenth century to accompany Chinese pentatonic melodies (Mittler 1997: 33).

33. The song was published on the SHCM's official WeChat account on 27 November 2018, and can be accessed at the following site: https://www.youtube.com/watch?v=nNueiOHIGjk (accessed on 19 July 2019).

34. The preface to this brochure, written by the SHCM's Director, Lin Zaiyong, comments on the institution's motto in these terms: "The essence of harmony lies in the search for similarities among apparent differences, so that the five flavours may be complementary to one another, and the eight notes also, in a harmonious coordination, so that each and every person may be sociable (but without aiming to get involved in small associations) and that everyone may come together to be as one" (he zhi ao yi, yi zhong qiu tong, wu wei xiang ji, bayin xiangxie, qun er bu si, he zhong er yi 和之奧義, 異中求同, 五味相濟, 八音相協, 群而不私, 合眾而一). 
baton being offered to the two children at the end of the song; or the importance of the gratitude expressed to the authorities, as embodied by the prominence of the bust of Xiao Youmei that appears in the foreground right from the opening notes of the baritone's song. One final observation that can be made concerns the staging of the video of the song, which reveals an interplay between the dialogue of the four soloists. Forming two couples, the first clad in traditional dress and the other in Western fashion, they symbolise not only the twin components of the piece, international and national, but also the interaction between an international and traditional dimension.

\section{Analysis and discussion}

The musical examples presented here participate in the re-creation of a musical territory: musicians of the Shanghai Conservatory are creating a musical object, dominated by a particular rhetoric with certain fundamental socio-political elements, related to the status of Western classical music, such as prestige, success, and international recognition. Both of these musical productions illustrate a particular approach to Western classical music based on a savoir-faire for producing an object that is "recomposed," as it were, from references that are mainly Western, and that mobilises a musical rhetoric in the service of a specific discourse: melodic motifs on a pentatonic scale but that still fall within a tonal conception of music, whether that of the lyricism of Italian bel canto or Wagnerian progression, etc. The result is presented as a "national" object that aims to associate reference points of a political nature to a precise range of emotions.

These compositions also reflect a creative concept characterised especially by a collective approach within a particular "situated" social space, through a predilection for musical material and highly globalised forms, as well as by a combination of musical styles freed from official rules in the strictest Western tradition, indeed even to the point of indulging in post-modernism. This latter element is markedly opposed to the musical creations produced within most European conservatories, which generally maintain the principle of creation as dependent on the "Romantic" myth of breaking with form and tradition without calling into question certain lines of demarcation between different forms, styles, and genres. As the ethnomusicologist Martin Stoke reminds us, creation "is a value attached to certain forms of cultural transmission, often positive in nature, and is therefore a deeply ideological category" (Stokes 2014).

The two compositions cited thus constitute examples of a certain type of appropriation of Western classical music - or certain elements of it, at least - to political ends. The genre that they illustrate is not the only one, however, to fulfil this function. Another type of musical object, one that falls within the domain of a new faculty of the Shanghai Conservatory, also plays this role. This new faculty, set up on 18 October 2018 as an emanation of the Centre of Ideology and Politics, has the mission, just like the two songs illustrated above, of promoting research on Chinese "Red music" and its development. ${ }^{36}$ The research to be conducted in this new faculty concerns musical creations based on a revolutionary theme, from the 1930s until the present day, with the primary objective being to spread and develop this "red music." In practice, it is about reconstructing a posteriori a historical object - a musical style - by bringing together under one banner different sorts of musical works, produced in a variety of contexts, which supposedly share the same revolutionary features. ${ }^{37}$ "Red music" would therefore seem to be a form of nationalist music par excellence that would be worthy of a separate study in its own right, but with respect to which we will simply make the observation here that, unlike the cases we have examined above, it is not fundamentally based on the same appropriation of Western classical music.

\section{Conclusion}

The examples presented here illustrate a type of composition that can be found in other musical objects with similar musical features that also display an explicit political dimension. One example is that of an opera created by the Shanghai Conservatory, based on a work by He Lüting, which premiered on 4 September 2018. The official aims of this work were, in particular, "to study and apply socialism with Chinese characteristics of the new era," that is to say, such as proposed by Xi Jinping, and "to promote and develop China's excellent traditional culture."

These various works are testimony to the way in which the appropriation of Western classical music by an institution such as the Shanghai Conservatory of Music occurs on at least two levels. The first involves a mastery of the object, making a selection from the entire repertoire so as to include only composers and works that enable the institution to fulfil its objective of forming soloists capable of winning international competitions. The second, still about mastery, is an insistence on technique and learning "by heart," keeping the score at a distance through a scientific approach to the musical object: everything that has a connection to Western classical music, treated above all in terms of a technique to be acquired, and developed in the context of a strong commitment to the globalisation of training within the institution, whose primary aim is to put into music a discourse that is first and foremost political, by means of a targeted rhetoric and under the supervision of the head of the SHCM and the Centre of Ideology and Politics.

My exchanges with several students at the Shanghai Conservatory show that the trend towards the creation of songs of this kind is on the rise. It does not meet with universal approval, however. I observed that some members of the Conservatory kept their distance with respect to this, and even expressed some criticism of the finished product by completing their generally laconic comments with a smile or sign of embarrassment. These reactions question the effectiveness of the propagandist objectives of such music. They also allow one to think that it is not the students and teachers who are the target of such propaganda, or even the general public; one may speculate that it is politicians themselves who are the privileged audience for these videos.

\section{Translated by Peter Brown.}

\section{Eugénie Grenier Borel teaches at the Geneva Conservatoire populaire} de musique, danse et théâtre (CPMDT). She holds a Master's degree in ethnomusicology from the Universities of Neuchâtel and Geneva and has been pursuing her studies at the doctoral level since October 2019. Her research deals with the rhetoric of Chinese conservatories concerning Western classical music, with a particular focus on the Shanghai Conservatory (eugenie.grenier@unine.ch).

\section{Manuscript received on 13 March 2019. Accepted on 15 July 2019.}

35. Joys Hoi Yan Cheung relates that Xiao Youmei (1934) emphasised how, through the difficult lives they led (sickness and poverty), "the musical maestros" and the "wise European men of music" embodied Chinese virtues. In order to write about the Confucian virtues in their lives, Xiao Youmei praised Schumann not only for having "overcome illness" but also for having been a faithful student. The respect Brahms had towards the model composers of the past shows his "esteem for the force of example."

36. The SHCM lauds this faculty as being the top national academic body specialising in this field. This echoes the institution's overall claim to be the foremost Conservatory in China that specialises in the teaching of Western classical music, as an imported international model that is turned towards the West.

37. According to the notice on the SHCM's official WeChat account, dated 19 October 2018. 


\section{References}

BARABANTSEVA, Elena. 2008. "From the Language of Class to the Rhetoric of Development: Discourses of 'Nationality' and 'Ethnicity' in China." Journal of Contemporary China 17(56): 565-89.

BECKER, Howard S. 1982. Art Worlds. Berkeley and Los Angeles: University of California Press.

BECKER, Howard S. 1963. Outsiders: Studies in the Sociology of Deviance. London: Free Press of Glencoe.

CALLAHAN, William, and Elena BARABANTSEVA. 2011. China Orders the World. Baltimore: The Johns Hopkins University Press.

CHEUNG, Joys Hoi Yan. 2008. Chinese Music and Translated Modernity in Shanghai, 1918-1937. Michigan: University of Michigan.

CLARKE, Éric. 2004. "Les processus cognitifs dans l'interprétation" (Cognitive processes during interpretation). In Jean-Jacques Nattiez (ed.), Musiques. Une Encyclopédie pour le XXle Siècle (Music, An encyclopaedia for the XX|trt century).Vol. 2. Arles and Paris: Actes Sud/Cité de la Musique. 342-58.

COOK, Nicholas. 1998. Music, A Very Short Introduction. New York: Oxford University Press.

El-GHADBAN, Yara. 2009. "Facing the Music: Rituals of Belonging and Recognition in Contemporary Western Art Music." American Ethnologist 36(1): 140-60.

FABBRI, Franco. 2001."La chanson"(The song).In Jean-Jacques Nattiez (éd.), Musiques. Une encyclopédie pour le XXIe siècle (Music, An encyclopaedia for the XX|st century).Vol. 1. Arles and Paris: Actes Sud/Cité de la Musique. 674-702.

GELBART, Matthew. 2011 The Invention of "Folk Music" and "Art Music": Emerging Categories From Ossian to Wagner. Cambridge: Cambridge University Press.

HERTZ, Ellen. 2009. "L'événement : l'espace-temps de la reconnaissance" (The event: the space-time of recognition). In Francine Saillant (ed.), Réinventer l'Anthropologie ? Les sciences de la culture à l'épreuve des globalisations (Re-inventing anthropology? Cultural studies facing the challenge of globalisations). Montreal: Carrefours anthropologiques, Liber. 205-20.

GONG, Hong-yu. 2016. "Music to Teach and Transform." Journal of Music in China 6(1): 75-98.

HUANG, Hao. 2012. "Why Chinese People Play Western Classical Music: Transcultural Roots of Music Philosophy." International Journal of Music Education 2: 161-76.

JONES, Andrew F. 1997. Like a Knife, Ideology and Genre in Contemporary Chinese Popular Music. New York: Cornell University.

KINGSBURY, Henry. 1988. Music, Talent and Performance: A Conservatory Cultural System. Philadelphia: Temple University Press.

KIPNIS, Andrew. 2011. Governing Educational Desire System. Culture, Politics and Schooling in China. Chicago: The University of Chicago Press.

KRAUS, Richard. 1989. Pianos and Politics in China: Middle-class Ambitions and the Struggle over Western Music. Oxford: Oxford University Press.
LIU, Ching-chih 劉靖之. 2009. 中國新音樂史論 (Zhongguo xin yinyue shilun, A critical history of new music in China). Hong Kong: Zhongwen daxue chubanshe.

MEEÙS, Nicolas. "Polyphonie, harmonie, tonalité" (Polyphony, harmony, key). In Jean-Jacques Nattiez (ed.), Musiques. Une encyclopédie pour le XX/e Siècle (Music, An encyclopaedia for the XX|st century). Vol. 2. Arles and Paris: Actes Sud/Cité de la Musique. 116-33.

MELVIN, Sheila, and Jindong CAl. 2004. Rhapsody in Red: How Western Classical Music Became Chinese. New York: Algora Publishing.

MITTLER, Barbara. 1997. Dangerous Tunes: The Politics of Chinese Music in Hong Kong, Taiwan, and the People's Republic of China since 1949. Wiesbaden: Otto Harrassowitz Verlag.

NOOSHIN, Laudan. 2011. "Introduction to the Special Issue: The Ethnomusicology of Western Art Music." Ethnomusicology Forum 20(3): 285-300.

RINGEN, Stein. 2016. The Perfect Dictatorship. Hong Kong: Hong Kong University Press.

ROCCA, Jean-Louis. 2010. Une sociologie de la Chine (A sociology of modern China). Paris: La Découverte.

SCHIMMELPENNINCK, Annette, and Frank KOUWENHOVEN. 1993. "The Shanghai Conservatory of Music: History and Foreign Students' Experiences." Chime, Journal of the European Foundation for Chinese Research 6: 56-91.

STOKES, Martin. 2014. "Creativity, Clobalization and Music." La revue des musiques populaires 10(2): 29-45.

TARUFI, Johannella. 2004. "La formation musicale supérieure" (Advanced music education). In Jean-Jacques Nattiez (ed.), Musiques. Une encyclopédie pour le XX/e Siècle (Music, An encyclopaedia for the XX|jt century).Vol. 2. Arles and Paris:Actes Sud/Cité de la Musique. 873-98.

THORAVAL, Joël. 1999. "'Ethnicity' as Applied to the Chinese Cutlural World." China Perspectives 25(September-October): 44-59.

TRÉBINJAC, Sabine. 2000. Le pouvoir en chantant (Power through singing). Nanterre: Société d'ethnologie.

VENDRIX, Philippe. 2004. "Les conceptions de l'histoire de la musique" (Conceptions of music history). In Jean-Jacques Nattiez (ed.), Musiques. Une encyclopédie pour le XXle siècle. (Music, An encyclopaedia for the XX|st century).Vol. 2. Arles and Paris:Actes Sud/Cité de la musique. 628-48.

WACQUANT, Loïc. 2000. Corps et âme, carnet ethnographiques d'un apprenti boxeur (Body and soul: Notebooks of an apprentice boxer). Marseille: Agone, Comeau \& Nadeau.

XI, Jinping, 2014. La gouvernance de la Chine (The governance of China). Beijing: Les éditions en langues étrangères.

XIAO, Youmei 蕭友梅. 1934. 音樂家的新生活 (Yinyuejia de xin shenghuo, The new life of musicians). Nanjing: Zhengzhong shuju.

YASUKO, Enamoto 榎本泰子. 1998. 人の都・上海: 近代中国における西洋 音楽の受容 (Gakunin no miyako kindai. Shanghai: Chugoku ni okeru seiyo ongaku no juyo, Shanghai, capital of musicians: The beginnings of Western music in contemporary China). Tokyo: Kenbun Shuppan 研文書版社. 